\title{
Metode Double Exponential Smoothing pada Sistem Peramalan Tingkat Kemiskinan Kabupaten Pangkep
}

\author{
Nur Almar'Atussaliha a,1,*, Purnawansyah a,2 dan Herdianti Darwis ${ }^{\mathrm{a}, 3}$ \\ ${ }^{a}$ Universitas Muslim Indonesia, Urip Sumoharjo km.05 Kampus II UMI, Makassar, 90231, Indonesia \\ ${ }^{1}$ almaratussalihanur@gmail.com; ${ }^{2}$ purnawansyah@umi.ac.id; ${ }^{3}$ herdianti.darwis@umi.ac.id \\ *corresponding author
}

\begin{tabular}{|c|c|}
\hline INFORMASI ARTIKEL & ABSTRAK \\
\hline $\begin{array}{l}\text { Dikirim : } 17 \text { Juli } 2020 \\
\text { Diulas } \quad: 06 \text { Desember } 2020 \\
\text { Direvisi } \quad: 06 \text { Desember } 2020 \\
\text { Diterbitkan }: 28 \text { Desember } 2020 \\
\text { Kata Kunci: } \\
\text { Peramalan } \\
\text { Kemiskinan } \\
\begin{array}{l}\text { Double Exponential Smoothing } \\
\text { Mean Absolute Percentage Error }\end{array}\end{array}$ & $\begin{array}{l}\text { Peramalan adalah kegiatan memperkirakan kejadian yang akan terjadi } \\
\text { berdasarkan historical data kuantitatif suatu kejadian. Peramalan sering } \\
\text { digunakan oleh pemerintah dalam membuat suatu kebijakan. Salah satu } \\
\text { kebijakan pemerintah adalah menurunkan angka kemiskinan setiap tahunnya. } \\
\text { Penelitian ini bertujuan untuk membangun sistem Peramalan Tingkat } \\
\text { Kemiskinan Kabupaten Pangkep berbasis desktop untuk memberikan } \\
\text { gambaran jumlah tingkat kemiskinan periode selanjutnya. Dalam penelitian } \\
\text { ini, metode peramalan yang digunakan adalah Double Exponential Smoothing } \\
\text { dengan nilai alpha } 0.001,0.01,0.2,0.3,0.5,0.7,0.8,0.99 \text {, dan } 0.999 \text {. Dengan } \\
\text { menggunakan data angka kemiskinan dari tahun } 2010 \text { sampai } 2019 \text {, diperoleh } \\
\text { bahwa dari } 9 \text { nilai alpha yang digunakan, tingkat kesalahan terkecil yaitu } 1.2 \% \\
\text { diberikan oleh alpha } 0.5 \text { yang diukur menggunakan metode Mean Absolute } \\
\text { Percentage Error (MAPE). Adapun tingkat akurasi peramalan yang } \\
\text { didapatkan jumlah kesalahan tiap alpha sebesar } 95.394 \% \text {. }\end{array}$ \\
\hline $\begin{array}{l}\text { Keywords: } \\
\text { Forecasting } \\
\text { Poverty } \\
\text { Double Exponential Smoothing } \\
\text { Mean Absolute Percentage Error }\end{array}$ & $\begin{array}{l}\text { ABSTRACT } \\
\text { Forecasting is the activity of estimating an event that will occur based on the } \\
\text { quantitative historical data. Forecasting is often used by the government in } \\
\text { making policies which one of them is to reduce the annual poverty rate. This } \\
\text { research aims to build a desktop-based application of Poverty rate forecasting } \\
\text { system providing an idea of poverty level in the next periods. In this research, } \\
\text { Double Exponential Smoothing is used with } 9 \text { different kinds of alpha values } \\
\text { namely } 0.001,0.01,0.2,0.3,0.5,0.7,0.8,0.99 \text {, and } 0999 \text {. Using the poverty } \\
\text { rate data from } 2010 \text { to } 2019 \text { the smallest error rate of } 9 \text { kinds of alphas is } 1.2 \% \\
\text { provided by alpha } 0.5 \text { which is measured using Mean Absolute Percentage } \\
\text { Error (MAPE) method. In conclusion, Double Exponential Smoothing could } \\
\text { successfully deal with poverty rate forecasting evidenced by } 95.395 \% \text { of } \\
\text { forecasting accuracy obtained from the result. }\end{array}$ \\
\hline
\end{tabular}

This is an open access article under the CC-BY-SA license.

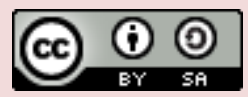

\section{Pendahuluan}

Kemiskinan masih menjadi masalah kompleks yang dihadapi pemerintah saat ini. Pemerintah menempatkan masalah kemiskinan menjadi isu utama dalam pembangunan daerah [1]. Menurut BPS, kemiskinan dipandang sebagai ketidakmampuan memenuhi kebutuhan dasar makanan dan kebutuhan bukan makanan yang diukur dari sisi pengeluaran [2]. Beberapa faktor yang mempengaruhi kemiskinan antara lain tingkat pendapatan masyarakat, pengangguran, kesehatan, pendidikan, akses terhadap barang dan jasa, serta lingkungan dan geografis [3].

Badan Pusat Statistik (BPS) Sulawesi Selatan mencatat ada dua wilayah dengan jumlah penduduk miskin terbanyak yaitu Kabupaten Jeneponto dan Kabupaten Pangkep [4]. Angka kemiskinan Kabupaten Pangkep selama tahun 2013 sampai 2019 [5] mengalami penurunan meskipun fluktuatif, angka tersebut masih kategori miskin yang cukup tinggi jika dibandingkan dengan kabupaten lain di Sulawesi Selatan.

Dengan permasalahan tersebut, maka diperlukan suatu upaya untuk mengetahui seberapa besar kenaikan atau penurunan penduduk miskin Kabupaten Pangkep dalam beberapa tahun kedepan. Untuk mengatasi masalah tersebut diperlukan peramalan (forecasting) sebagai suatu solusi untuk memprediksi suatu kejadian. 
Peramalan merupakan kegiatan memperkirakan kejadian yang akan terjadi pada masa akan datang berdasarkan data yang relevan dengan masa lalu yang dianalisis secara ilmiah menggunakan metode statisktik [6]. Peramalan dibutuhkan karena adanya kesenjangan waktu (timelag) antara kesadaran dibutuhkan suatu kebijakan dengan waktu pelaksanaan kebijakan tersebut[7], sehingga peramalan begitu penting dan dijadikan patokan bagi pemerintah dalam mengambil keputusan dan menentukan suatu kebijakan [8].

Berdasarkan penelitian sebelumnya yang dilakukan oleh Surya Agus Yasinta dan Yulia Yudihartani [9] terkait prediksi daya sambung, hasil penelitian yang didapatkan dengan menggunakan metode Double Exponential Smoothing menggunakan 25 data menghasilkan tingkat akurasi sebesar 88\% lebih tinggi jika dibandingkan dengan perkiraan manual. Kemudian penelitian selanjutnya yang dilakukan oleh Urai Icha Anjani [10] terkait prediksi permintaan kopi bubuk, hasil penelitian yang didapatkan menggunakan metode Double Exponential Smoothing dengan data bulanan dari Januari 2017 sampai Desember 2018 menghasilkan tingkat akurasi sebesar $83.76 \%$. Berdasarkan hasil penelitian yang dilakukan oleh dua peneliti tersebut, dapat disimpulkan bahwa metode Double Exponential Smoothing dapat memberikan tingkat akurasi peramalan yang sangat baik dengan jumlah data yang sedikit.

Penelitian ini bertujuan untuk membangun Sistem Peramalan Tingkat Kemiskinan Kabupaten Pangkep menggunakan metode Double Exponential Smoothing yang bertujuan untuk memberikan gambaran berupa tingkat kemiskinan untuk periode selanjutnya.

\section{Metode}

A. Peramalan

Dalam kehidupan segala sesuatu itu tidak pasti dan sukar untuk diperkirakan secara pasti, sehingga diperlukan peramalan [11]. Terdapat dua hal pokok dilakukan dalam melakukan peramalan dengan akurat dan bermanfaat yaitu pengumpulan data relevan berupa informasi yang menghasilkan peramalan akurat dan kedua memilih metode peramalan yang tepat digunakan dalam mengolah informasi berdasarkan data yang telah dikumpulkan [12]. Terdapat tiga model dalam menganalisis peramalan, yaitu model ekonometrika, model deret waktu (time series), dan model peramalan kualitatif. Exponential Smoothing salah satu model time series dengan perhitungan secara terus menerus menggunakan data yang baru [13].

\section{B. Double Exponential Smoothing (DES)}

Double Exponential Smoothing adalah model linear yang dikemukan oleh Brown, metode ini digunakan jika data menunjukkan adanya trend naik turun. Kelebihan dari metode ini menggunakan data yang sedikit dan menggunakan satu parameter sehingga lebih sederhana [10].

$$
\begin{aligned}
& {S^{\prime}}_{t}=\alpha \cdot X_{t}+(1-\alpha) S_{t-1}^{\prime} \\
& {S^{\prime \prime}{ }_{t}}^{\prime}=\alpha \cdot S^{\prime}+(1-\alpha) S^{\prime \prime}{ }_{t-1}
\end{aligned}
$$

Double Exponential Smoothing dilakukan dengan dua proses pemulusan yaitu pemulusan pertama dan pemulusan kedua dengan Persamaan (1) dan Persamaan (2).

$$
\begin{aligned}
& F_{t+m}=\propto_{t}+b_{t} m \\
& \propto_{t}=2 S^{\prime}-S^{\prime \prime} \\
& b_{t}=\frac{\alpha}{(1-\alpha)}\left(S^{\prime}{ }_{t}-S^{\prime \prime}{ }_{t}\right)
\end{aligned}
$$

Persamaan (3) digunakan untuk menghitung nilai peramalan dimasa akan datang, dengan nilai konstanta dan nilai trend diperoleh diperoleh dengan Persamaan (4) dan Persamaan (5).

Keterangan:

$S^{\prime}{ }_{t} \quad$ : nilai pemulusan eksponensial pertama

$X_{t} \quad$ : data aktual pada waktu $t ; t=1,2,3, \ldots n$

$S^{\prime \prime}{ }_{t} \quad$ : nilai pemulusan eksponensial kedua

$\alpha \quad$ : parameter pemulusan eksponensial besarnya $0<\alpha<1$

$S_{t-1}^{\prime} \quad$ : nilai hasil pemulusan pertama periode $\mathrm{t}$

$S^{\prime \prime}{ }_{t-1} \quad$ : nilai hasil pemulusan kedua periode $\mathrm{t}$

$\propto_{t} \quad$ : besarnya konstanta pada periode $\mathrm{t}$

$b_{t} \quad$ : besarnya nilai slope atau nilai trend pada periode $\mathrm{t}$

$F_{t+m}$ : nilai peramalan periode kedepan

$\mathrm{m} \quad$ : jangka waktu peramalan untuk periode kedepan $m=1,2,3, \ldots n$ 
C. Mean Absolute Percentage Error (MAPE)

Tidak ada suatu metode terbaik dalam melakukan suatu peramalan, metode yang memberikan hasil peramalan secara cepat belum tentu tepat jika digunakan pada kasus atau data yang lain [14]. Pada time series metode peramalan yang terbaik adalah metode yang menghasilkan nilai kesalahan atau nilai error yang kecil [14].

MAPE merupakan metode yang digunakan untuk menghitung ketepatan suatu peramalan. Metode ini menghitung selisih antara nilai data aktual dan nilai peramalan yang menghasilkan nilai mutlak. Perbedaan nilai tersebut dihitung dalam bentuk persentase, jika persentase nilai MAPE dibawah $10 \%$ artinya tingkat ketapatan peramalan tersebut sangat bagus sedangkan jika nilai MAPE berada antara $10 \%$ dan $20 \%$ maka ketepatan peramalan memiliki kinerja yang bagus [11]. Secara matematis nilai MAPE diperoleh menggunakan Persamaan (6).

$$
M A P E=\frac{\sum_{t=1}^{n} \frac{\left|X_{t}-F_{t}\right|}{X_{t}} \times 100}{n}
$$

Keterangan:

$X_{t} \quad$ : data aktual periode $t ; t=1,2,3, \ldots n$

$F_{t} \quad:$ nilai peramalan periode $\mathrm{t} ; t=1,2,3, \ldots n$

n : jumlah data

Setelah nilai MAPE didapatkan, maka dapat dilihat tingkat ketepatan hasil peramalan tersebut pada Tabel 1.

Tabel 1. Nilai Ketepatan MAPE

\begin{tabular}{cc}
\hline \multicolumn{2}{c}{ Persentase Ketepatan Nilai MAPE } \\
\hline Nilai $\mathbf{M A P E}$ & Kategori \\
\hline MAPE $\leq 10 \%$ & Sangat Baik \\
\hline $20 \%<$ MAPE $\leq 20 \%$ & Baik \\
\hline $20 \%<$ MAPE $\leq 50 \%$ & Reasonable \\
\hline MAPE $>50 \%$ & Buruk \\
\hline
\end{tabular}

Setelah mendapatkan nilai MAPE, selanjutnya menghitung tingkat akurasi peramalan. Secara matematis, tingkat akurasi peramalan dapat dihitung menggunakan Persamaan (7).

$$
\text { Persentase Keberhasilan }=100 \%-\sum M A P E
$$

Peramalan dikatakan bagus atau tidak berdasarkan koefisien tingkat akurasi peramalan [15] yang dihasilkan, tingkat keberhasilan akurasi peramalan dapat dilihat pada Tabel 2.

Tabel 2. Akurasi Tingkat Peramalan

\begin{tabular}{cc}
\hline & Persentase Tingkat Akurasi \\
\hline Nilai Akurasi & Kategori \\
\hline$>80 \%$ & Sangat Baik \\
\hline$>60 \%<80 \%$ & Baik \\
\hline$>40 \%<60 \%$ & Cukup \\
\hline$<40 \%$ & Rendah \\
\hline
\end{tabular}

\section{Hasil dan Pembahasan}

Sistem yang dibangun pada penelitian ini berbasis dekstop menggunakan Bahasa Pemrograman Java dan database MySQL.

1. Halaman Entry Data

Halaman entry data merupakan halaman yang digunakan untuk melakukan pengolahan data yang akan digunakan untuk menghitung nilai peramalan. Pengelolaan data kemiskinan dilakukan dengan menambahkan data secara pertahun kemudian data yang telah ditambahkan akan masuk kedalam database dan dapat dilihat pada tabel. Selain itu, halaman ini memungkinan pengguna untuk menghapus data dan mengubah datanya. Halaman kelola data dapat dilihat pada Gambar 1. 


\section{SISTEM PERAMALAN TINGKAT KEMISKINAN}

\section{KABUPATEN PANGKAJENE DAN KEPULAUAN}

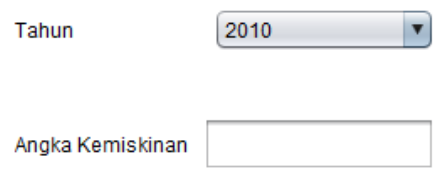

Simpan

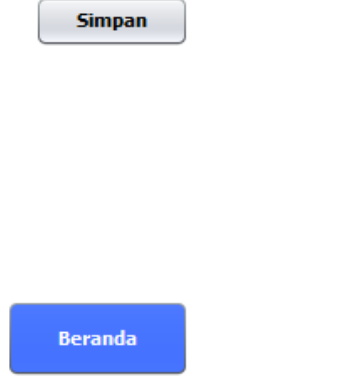

\begin{tabular}{|l|l|l|}
\hline Id Data & Tahun & Angka Kemiskinan \\
\hline 57 & 2010 & 59000 \\
58 & 2011 & 53700 \\
59 & 2012 & 51800 \\
60 & 2013 & 56400 \\
61 & 2014 & 52600 \\
\hline 62 & 2015 & 53850 \\
\hline 63 & 2016 & 52860 \\
61 & 2017 & 53280 \\
\hline
\end{tabular}

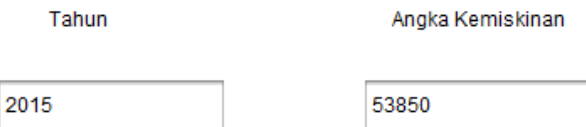

Update

\section{Hapus}

Gambar 1. Halaman Entry Data

2. Halaman Hasil Perhitungan

Halaman hasil perhitungan yaitu halaman yang menampilkan hasil perhitungan berdasarkan angka yang telah diinput pada halaman kelola data. Data dihitung oleh sistem dan ditampilkan dalam bentuk tabel berdasarkan pemilihan nilai alpha dengan menampilkan hasil kesalahan peramalan (MAPE) seperti pada Gambar 2.

\section{SISTEM PERAMALAN TINGKAT KEMISKINAN}

\section{KABUPATEN PANGKAJENE DAN KEPULAUAN}

\begin{tabular}{|l|l|}
\hline Tahun & Angka Kemiskinan \\
\hline 2010 & 59000 \\
2011 & 53700 \\
2012 & 51800 \\
2013 & 56400 \\
2014 & 52600 \\
2015 & 53850 \\
2016 & 52860 \\
\hline
\end{tabular}

Alpha

0.5

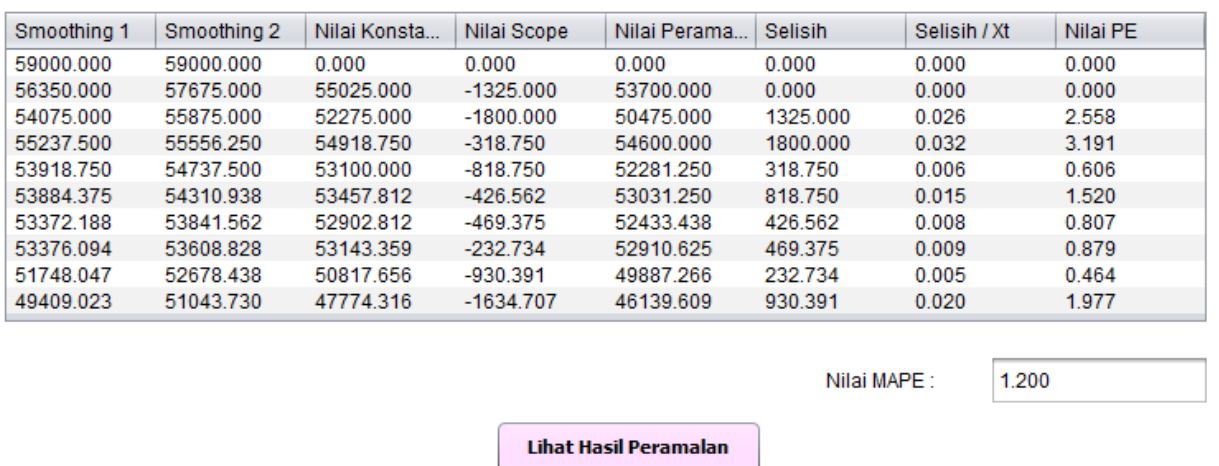

Gambar 2. Halaman Hasil Perhitungan 
3. Halaman Hasil Peramalan

Setelah melihat hasil perhitungan berdasarkan nilai alpha dan melihat nilai kesalahan tiap alpha yang dihitung dengan MAPE pada halaman hasil perhitungan. Maka selanjutnya melihat hasil peramalan. Hasil peramalan berisi hasil perhitungan berdasarkan nilai alpha dan nilai MAPE serta tingkat akurasi permalana. Halaman ini juga menampilkan hasil peramalan untuk periode 10 tahun kedepan dalam bentuk grafik. Halaman hasil peramalan dapat dilihat pada Gambar 3.

\section{SISTEM PERAMALAN TINGKAT KEMISKINAN}

\section{KABUPATEN PANGKAJENE DAN KEPULAUAN}

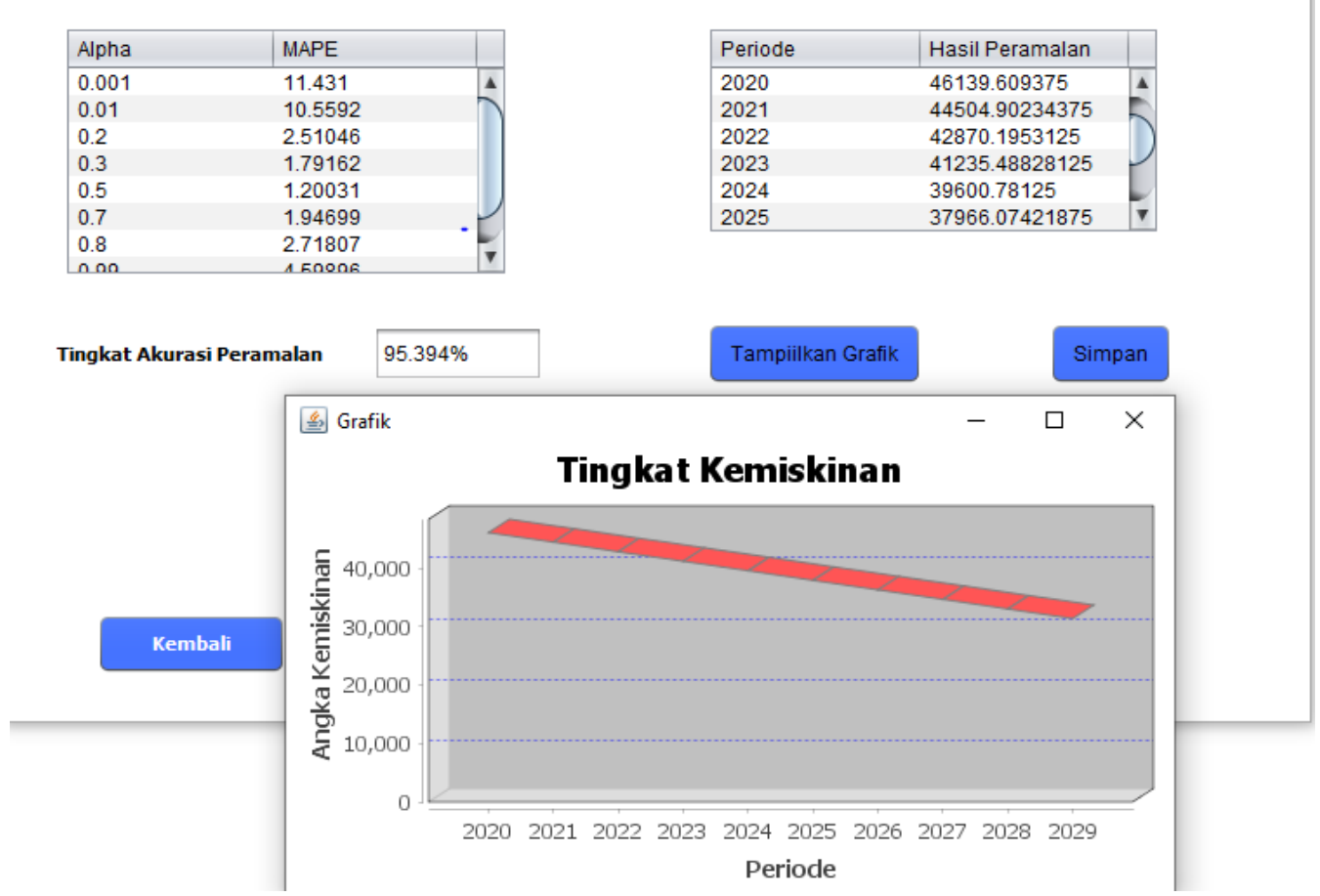

Gambar 3. Halaman Hasil Peramalan

Berikut uraian cara penerapana metode Double Exponential Smoothing dalam meramalkan tingkat kemiskinan Kabupaten Pangkep untuk 10 tahun kedepan.

Tahap 1: Analisi Data

Data yang digunakan dalam melakukan peramalan yaitu data kemiskinan pertahun Kabupaten Pangkep dalam 10 tahun terakhir yaitu data dari tahun 2010 sampai tahun 2019. Proses peramalan dilakukan untuk mencari nilai peramalan 10 tahun kedepannya. Perhitungan peramalan menggunakan nilai alpha 0.001, 0.01, 0.2, 0.3, 0.5, 0.7, 0.8, 0.99, 0.999. Berikut data tingkat kemiskinan yang ditunjukkan pada Tabel 3.

Tabel 3. Data Kemiskinan

\begin{tabular}{cc}
\hline Tahun & $\begin{array}{c}\text { Jumlah Penduduk Miskin (Ribu } \\
\text { Jiwa) }\end{array}$ \\
\hline 2010 & 59000 \\
\hline 2011 & 53700 \\
\hline 2012 & 51800 \\
\hline 2013 & 56400 \\
\hline 2014 & 52600 \\
\hline 2015 & 53850 \\
\hline 2016 & 52860 \\
\hline 2017 & 53380 \\
\hline 2018 & 50120 \\
\hline 2019 & 47070 \\
\hline
\end{tabular}


Tahap 2: Melakukan Perhitungan

Nilai alpha yang digunakan adalah 0.5

a. Menghitung nilai pemulusan pertama $\left(S^{\prime}\right)$ berdasarkan persamaan (1)

$$
\begin{aligned}
& {S^{\prime}}_{1}=59000 \\
& {S^{\prime}}{ }_{2}=(0.5) * 53700+(1-0.5) * 59000=56350.000 \\
& {S^{\prime}}{ }=(0.5) * 51800+(1-0.5) * 56350.000=54075.000 \\
& {S^{\prime}}{ }_{4}=(0.5) * 56400+(1-0.5) * 54075.000=55237.500 \\
& {S^{\prime}}{ }_{5}=(0.5) * 52600+(1-0.5) * 55237.500=53918.750 \\
& S^{\prime}{ }_{6}=(0.5) * 53850+(1-0.5) * 53918.750=53884.375 \\
& S^{\prime}{ }_{7}=(0.5) * 52860+(1-0.5) * 53884.375=53372.188 \\
& S^{\prime}{ }_{8}=(0.5) * 53380+(1-0.5) * 53372.188=53376.094 \\
& S^{\prime}{ }_{9}=(0.5) * 50120+(1-0.5) * 53376.094=51748.047 \\
& S^{\prime}{ }_{10}=(0.5) * 47070+(1-0.5) * 51748.047=49409.023
\end{aligned}
$$

b. Menghitung nilai pemulusan kedua $\left(S^{\prime \prime}\right)$ berdasarkan persamaan (2)

$$
\begin{aligned}
& S^{\prime \prime}{ }_{1}=59000 \\
& S^{\prime \prime}{ }_{2}=(0.5) * 56350.000+(1-0.5) * 59000=57675.000 \\
& S^{\prime \prime}{ }_{3}=(0.5) * 54075.000+(1-0.5) * 57675.000=55875.000 \\
& S^{\prime \prime}{ }_{4}=(0.5) * 55237.500+(1-0.5) * 55875.000=55556.250 \\
& S^{\prime \prime}{ }_{5}=(0.5) * 53918.750+(1-0.5) * 55556.250=54737.500 \\
& S^{\prime \prime}{ }_{6}=(0.5) * 53884.375+(1-0.5) * 54737.500=54310.938 \\
& S^{\prime \prime}{ }_{7}=(0.5) * 53372.188+(1-0.5) * 54310.938=53841.563 \\
& S^{\prime \prime}{ }_{8}=(0.5) * 53376.094+(1-0.5) * 53841.563=53608.828 \\
& S^{\prime \prime}{ }_{9}=(0.5) * 51748.047+(1-0.5) * 53608.828=52678.438 \\
& S^{\prime \prime}{ }_{10}=(0.5) * 49409.023+(1-0.5) * 52678.438=51043.730
\end{aligned}
$$

c. Menghitung nilai konstanta $\left(\propto_{t}\right)$ berdasarkan persamaan (3)

$$
\begin{aligned}
& \propto_{1}=0 \\
& \propto_{2}=2(56350.000)-57675.000=55025.000 \\
& \propto_{3}=2(54075.000)-55875.000=52275.000 \\
& \propto_{4}=2(55237.500)-55556.250=54918.750 \\
& \propto_{5}=2(53918.750)-54737.500=53100.000 \\
& \propto_{6}=2(53884.375)-54310.938=53457.813 \\
& \propto_{7}=2(53372.188)-53841.563=52902.813 \\
& \propto_{8}=2(53376.094)-53608.828=53143.359 \\
& \propto_{9}=2(51748.047)-52678.438=50817.656 \\
& \propto_{10}=2(49409.023)-51043.730=47774.316
\end{aligned}
$$

d. Menghitung nilai scope $\left(b_{t}\right)$ berdasarkan persamaan (4)

$$
\begin{aligned}
& b_{1}=0 \\
& b_{2}=\frac{0.5}{(1-0.5)}(56350.000-57675.000)=-1325.000 \\
& b_{3}=\frac{0.5}{(1-0.5)}(54075.000-55875.000)=-1800.000 \\
& b_{4}=\frac{0.5}{(1-0.5)}(55237.500-55556.250)=-318.750 \\
& b_{5}=\frac{0.5}{(1-0.5)}(53918.750-54737.500)=-818.750 \\
& b_{6}=\frac{0.5}{(1-0.5)}(53884.375-54310.938)=-426.563 \\
& b_{7}=\frac{0.5}{(1-0.5)}(53372.188-53841.563)=-469.375 \\
& b_{8}=\frac{0.5}{(1-0.5)}(53376.094-53608.828)=-232.734 \\
& b_{9}=\frac{0.5}{(1-0.5)}(51748.047-52678.438)=-930.391 \\
& b_{10}=\frac{0.5}{(1-0.5)}(49409.023-51043.730)=-1634.707
\end{aligned}
$$

e. Menghitung nilai peramalan $\left(F_{t}\right)$ berdasarkan persamaan (5)

$$
\begin{aligned}
& F_{1}=0 \\
& F_{2}=\propto_{2}+b_{2}=55025.000+(-1325.000)=53700.000 \\
& F_{3}=\propto_{3}+b_{3}=52275.000+(-1800.000)=50475.000 \\
& F_{4}=\propto_{4}+b_{4}=54918.750+(-318.750)=54600.000 \\
& F_{5}=\propto_{5}+b_{5}=53100.000+(-818.750)=52281.250
\end{aligned}
$$




$$
\begin{aligned}
& F_{6}=\propto_{6}+b_{6}=53457.813+(-426.563)=53031.250 \\
& F_{7}=\propto_{7}+b_{7}=52902.813+(-469.375)=52433.438 \\
& F_{8}=\propto_{8}+b_{8}=53143.359+(-232.734)=52910.625 \\
& F_{9}=\propto_{9}+b_{9}=50817.656+(-930.391)=49887.266 \\
& F_{10}=\propto_{10}+b_{10}=47774.316+(-1634.707)=46139.609
\end{aligned}
$$

Tahap 3: Mencari Nilai MAPE

Nilai MAPE didapatkan dengan mencari selisih nilai mutlak selisih antara data aktual dan nilai hasil peramalan berdasarkan persamaan (6).

$$
\begin{aligned}
M A P E & =\frac{12.003}{10} \\
& =1.200 \%
\end{aligned}
$$

Berikut nilai MAPE berdasarkan tiap alpha pada Tabel 4.

Tabel 4. Nilai MAPE

\begin{tabular}{cc}
\hline Alpha & MAPE \\
\hline 0.001 & $11.431 \%$ \\
\hline 0.01 & $10.559 \%$ \\
\hline 0.2 & $2.510 \%$ \\
\hline 0.3 & $1.792 \%$ \\
\hline 0.5 & $1.200 \%$ \\
\hline 0.7 & $1.947 \%$ \\
\hline 0.8 & $2.718 \%$ \\
\hline 0.99 & $4.599 \%$ \\
\hline 0.999 & $4.696 \%$ \\
\hline Rata-rata & $4.606 \%$ \\
\hline
\end{tabular}

Dari Tabel 4, dapat disimpulkan bahwa nilai alpha yang memiliki tingkat kesalahan terkecil adalah alpha 0.5. Sehingga untuk melakukan perhitungan peramalan pada periode berikutnya mengacu pada hasil perhitungan alpha 0.5 . Berikut hasil perhitungan untuk peramalan untuk 10 periode selanjutnya.

$F_{10+1}=\propto_{10}+b_{10}(1)$

$$
F_{t+m}=\propto_{t}+b_{t} m
$$

$F_{11}=47774.316+(-1634.707) *(1)=46139.609$

$F_{12}=47774.316+(-1634.707) *(2)=44504,902$

$F_{13}=47774.316+(-1634.707) *(3)=42870,195$

$F_{14}=47774.316+(-1634.707) *(4)=41235,488$

$F_{15}=47774.316+(-1634.707) *(5)=39600,781$

$F_{16}=47774.316+(-1634.707) *(6)=37966,074$

$F_{17}=47774.316+(-1634.707) *(7)=36331,367$

$F_{18}=47774.316+(-1634.707) *(8)=34696,660$

$F_{19}=47774.316+(-1634.707) *(9)=33061,953$

$F_{20}=47774.316+(-1634.707) *(10)=31427,246$

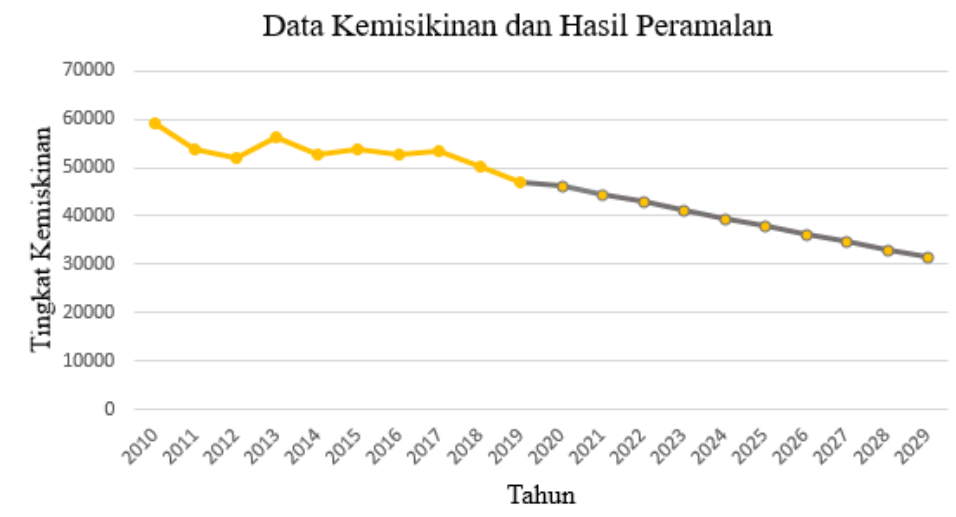

Gambar 4. Grafik Tingkat Kemiskinan dan Hasil Peramalan 
Berdasarkan grafik pada Gambar 4 yang menunjukkan hasil peramalan dari tahun 2020 sampai tahun 2029 mengalami trend penurunan.

Selanjutnya menghitung akurasi peramalan berdasarkan persamaan (7).

$$
\begin{aligned}
\text { Tingkat Akurasi Peramalan } & =100 \%-4.606 \% \\
& =95.394 \%
\end{aligned}
$$

Berdasarkan hasil pengujian dengan perhitungan metode Double Exponential Smoothing sebanyak 10 data kemiskinan nilai MAPE terkecil terdapat pada alpha 0.5 dan hasil akurasi peramalan sebesar $95.394 \%$ yang artinya tingkat akurasi sangat baik.

\section{Kesimpulan}

Hasil peramalan menghasilkan nilai optimal yang ditunjukkan dengan hasil kesalahan peramalan (Mean Absolute Percentage Error) pada alpha 0.5 sebesar $1.2 \%$ yang artinya memiliki kinerja sangat bagus. Hasil peramalan sangat dipengaruhi oleh banyaknya data dan nilai pada data sehingga tidak semua hasil peramalan akan memiliki tingkat kesalahan terkecil pada alpha 0.5. Metode Double Exponential Smoothing pada Peramalan Tingkat Kemiskinan Kabupaten Pangkep memiliki tingkat akurasi prediksi sebesar 95.394\% yang artinya hasil peramalan sangat baik.

\section{Daftar Pustaka}

[1] N. Suhandi, E. Ayu, and S. Agnisa, "Analisis Pengaruh Jumlah Penduduk terhadap Jumlah Kemiskinan Menggunakan Metode Regresi Linear di Kota Palembang," J. Ilm. Inform. Glob., vol. 09, no. 2, pp. 77-82, 2018.

[2] "BPS Kabupaten Pangkajene dan Kepulauan." [Online]. Available: https://pangkepkab.bps.go.id/subject/23/kemiskinan.html. [Accessed: 03-Jul-2020].

[3] I. F. Talia, "Peramalan Pengangguran Menggunakan Metode Double Exponential Smoothing Di Provinsi Kalimantan Timur," Pros. Semin. Ilmu Komput. dan Teknol. Inf., vol. 4, no. 2, pp. 121-127, 2019.

[4] F. Khair, "BPS Sulsel: Penduduk Miskin Paling Banyak di Jeneponto," 2019. [Online]. Available: http://news.rakyatku.com/read/173110/2019/12/09/bps-sulsel-penduduk-miskin-paling-banyak-dijeneponto. [Accessed: 03-Jul-2020].

[5] "BPS Kabupaten Pangkajene dan Kepulauan." [Online]. Available: https://pangkepkab.bps.go.id/dynamictable/2019/11/05/20/indikator-kemiskinan-kabupatenpangkajene-dan-kepulauan-2013-2018.html. [Accessed: 24-Apr-2020].

[6] Amiruddin and R. Ishak, "Prediksi Jumlah Mahasiswa Registrasi Per Semester Menggunakan Linier Regresi Pada Universitas Ichsan Gorontalo," Ilk. J. Ilm., vol. 10, no. 2, pp. 136-143, 2018.

[7] D. U. Rosa, "Metode Exponential Smoothing Dalam Memproyeksikan Jumlah Penduduk Miskin Di Nusa Tenggara Barat," J. Pemikir. dan Penelit. Pendidik. Mat., vol. 2, no. 1, pp. 42-53, 2019.

[8] A. Kumila, B. Sholihah, E. Evizia, N. Safitri, and S. Fitri, "Perbandingan Metode Moving Average dan Metode Naïve Dalam Peramalan Data Kemiskinan," JTAM | J. Teor. dan Apl. Mat., vol. 3, no. 1, pp. 65-73, 2019.

[9] S. A. Yasinta and Y. Yudihartanti, "Prediksi Daya Tersambung Dengan Metode Double Exponential Smoothing," JUTISI, vol. 5, no. 2, pp. 1151-1162, 2016.

[10] U. I. Anjani, "Prediksi Permintaan Produk Kopi Bubuk Menggunakan Metode Double Exponential Smoothing Berbasis Website (Studi Kasus: Pt. Fastrata Buana,” Coding J. Komput. dan Apl., vol. 08, no. 01, pp. 93-101, 2020.

[11] T. D. Andini and P. Auristandi, "Peramalan Jumlah Stok Alat Tulis Kantor di UD Achmad Jaya Menggunakan Metode Double Exponential Smoothing," J. Ilm. Teknol. Inf. Asia, vol. 10, no. 1, pp. 1-10, 2016.

[12] R. Wahyuni, "Peramalan Tingkat Produksi Tanaman Pangan Dan Tanaman Perkebunan Rakyat Kabupaten Bulukumba Menggunakan Metode Exponential Smoothing (Pemulusan Eksponensial)," Universitas Islam Negeri Alauddin Makassar, 2019.

[13] R. Y. Irawan, "Penerapan Metode Double Exponential Smoothing Untuk Peramalan Tingkat Indeks Pembangunan Manusia Berbasis Sistem Informasi Geografis Di Provinsi Jawa Tengah," $J$. TIKomSIN, vol. 7, no. 2, pp. 18-28, 2019.

[14] A. T. Putra, "Peramalan Jumlah Pengangguran di Sumatera Utara pada Tahun 2018-2020 dengan menggunakan Metode Pemulusan ( Smoothing ) Eksponensial Ganda," Universitas Sumatera Utara, 2019.

[15] H. Iskandar, "Prediksi Penjualan Laptop Menggunakan Single Exponential Smoothing Berbasis Web," J. CTIA, vol. 1, no. 1, pp. 17-22, 2019. 